\title{
Validation of Existing Arabic Language Reading Knowledge Instrument (SPSAMBA): Exploratory Factor Analysis (EFA)
}

\author{
Noorazi bin Rani, Harun Baharudin, Mohd Isa Hamzah \\ Faculty of Education, Universiti Kebangsaan Malaysia \\ razijapim@gmail.com, harunbaharudin@ukm.edu.my, isa_hamzah@ukm.edu.my
}

\begin{abstract}
This study aimed to review the Existing Arabic Language Reading Knowledge Instrument (SPSAMBA). A total of 150 trainee teachers in the field of Islamic Education and Arabic at the Institute of Teacher Education (IPG) were involved as respondents in this pilot study. Data analysis was descriptive using Alpha Cronbach reliability and factor exploration analysis (EFA) using SPSS software version 25. The results of the analysis found that the value of Alpha Cronbach obtained between 0.945-0.949 and the overall index value is 0.949 . Results from the EFA showed five existing knowledge factors with Eigenvalues each exceeding 1.0. The existing knowledge construct had a KMO Kaiser-Meyer-Olkin Measure of Sampling Adequacy value of 0.858>0.5. It proved that the items were sufficient for inter-correlation and Bartlett's Test of Sphericity (BToS) test was significant (Chi-Square 2157.699, $\mathrm{p}<0.05$ ), the anti-image value (Measure of Sampling Adequacy - MSA) for item correlation exceeded 0.5 with all items accepted and the total variance value explained by the five factors was 61.97 per cent. The overall findings recorded that the items for the existing knowledge instruments could measure and answer the objectives of the study.
\end{abstract}

Keywords:

existing knowledge; exploratory factor analysis (EFA)

Article Received: 18 October 2020, Revised: 3 November 2020, Accepted: 24 December 2020

\section{INTRODUCTION}

Learning a foreign language is an essential ingredient in the world of education. The development of studies related to language skills has been explored for a long time and is continuously evolving. Basic language skills that are given attention in language learning are listening, speaking, reading and writing (Gregersen 2006). A review of the literature found that these skills complement each other.

A review of the literature also found that the skills that often attract researchers are reading skills. It is because reading skills become the material for conveying information from informants to recipients of $\mathrm{t}$ information using only the medium of writing (Giovanelli \& Mason 2018). However, issues related to the effectiveness of reading skills are still debated, especially involving readers and reading materials. Furthermore, various factors influence reading ability, including interest, reading motivation, language proficiency and reader knowledge (Dahlia 2011). Thus, research related to one of the factors influencing reading ability that is the reader's existing knowledge in the context of Arabic as a foreign language was administered. However, due to the lack of instruments that could be used in the context of Arabic as a foreign language in Malaysia, this study attempted to test the questionnaire developed for that purpose.

\section{DEFINITION AND DIMENSION OF EXISTING KNOWLEDGE IN READING}

Existing knowledge, or also known as past knowledge, often gets the attention of researchers in the field of education. It refers to one's knowledge and experience. Existing knowledge is defined as the knowledge and skills or abilities that are present in the learning process (Dochy et al. 1999). Dochy (1994) outlined some characteristics of existing knowledge among them are (1) knowledge that is already available in a person (2) 
organised in a scheme of thought (3) able to express clearly and structured, (4) partly explicit and partly implicit, (5) is dynamic in nature with the environment and (6) is already stored in the repository of past knowledge.

A review of the literature found that existing knowledge is essential, especially involving the learning and facilitation process $(\mathrm{PdPc})$ primarily related to reading comprehension. Thus, Lyngfelt (2017) agreed that current knowledge is the first foundation for understanding reading material and helps to process the text read. This view further explains the claim of Rosenblatt (1988), who believed that reading is a processoriented activity. The process includes the reader creating word concepts, the process of observing text changes and guessing the desired meaning in mind. Therefore, the reader's understanding will grow and be developed according to the real wishes of the author.

Moreover, scholars also argued that existing knowledge is closely related to the process of reading and understanding the text. It can help speed up the reader's understanding. Thus, the information and experience that is available in the reader helps to relate the reading material to the background, culture, beliefs, beliefs and activities that the reader went through (Shukery \& Zaharah1999). Further, existing knowledge serves as a driver of reader interest and motivation (DuBay 2002). A review of the literature indicated that there was a pertinent correlation between existing interests and knowledge as well as these two variables had a significant impact on reading comprehension (Zulazhan 2012).

\section{THEORY AND MODELS THAT ARE THE BASIS OF INSTRUMENT DEVELOPMENT}

This questionnaire instrument was developed based on the Schema Theory in Reading and the Model of Prior Knowledge. Schema theory is one of the fastest-growing cognitive science disciplines. Briefly, scholars discuss this theory from the aspect of how human thought composes and structures information as well as thinking (Pankin 2013). The current data, knowledge and experience in the human memory compiled and structured are called a schema (Armbruster 1986).

Schematic theory in the context of reading attracted the attention of several scholars, including Rumelhalt as early as 1980, Carrell in 1981 and Hudson in 1982 when they discussed the basic principles of knowledge in reading comprehension (An 2013). A review of the literature reported that the characteristics of schemes in reading include (1) formal schemes, (2) content schema, (3) cultural schema (Urquhart \& Weir 1998) and (4) linguistic schema (Carrell 1984).

The model that also underlies the construction of this instrument is the Model of Prior Knowledge. This model was developed by Telle Hailikari, Nina Katajavuori and Sari Lindblom-Ylanne from the University of Helsinki, Finland. Existing knowledge has a strong influence on the acquisition of knowledge and the ability to master problem-solving skills (De Corte, 1990). It was also identified as one of the factors influencing the learning process and student achievement (Dochy 1994).

According to Hailikari et al. (2008) 'prior knowledge' is a multi-dimensional and hierarchical entity that is dynamic and consists of various types of knowledge and skills. This model categorised existing knowledge into two parts, namely; (1) existing knowledge of declarations, and (2) existing knowledge of procedures. Existing knowledge of declarations consists of knowledge of facts and knowledge of meaning. At the same time, existing knowledge of procedures involves the integration of knowledge and application of knowledge (Hailikari 2009).

Based on these theories and models, this study developed a questionnaire instrument by taking into account the elements found in Arabic as well as the elements of language in the context of Arabic as a foreign language. Once the questionnaire was formed, the instrument went through a process of validity and reliability of the instrument including pre-test, expert panel validation for content validity and face validity, exploratory factor analysis test (EFA) and pilot test. 


\section{EXPLORATORY FACTOR ANALYSIS (EFA)} FOR EXISTING KNOWLEDGE CONSTRUCT

Exploratory Factor Analysis (EFA) is a widely used procedure to identify variable components or factors. Exploratory Factor Analysis (EFA) is performed when a new measurement is developed or in the absence of theory (Hair et al. 2010). The procedure is able to determine the validity of the variables identified and tested (Schumacker \& Lomax, 2016). The advantage of Exploratory Factor Analysis (EFA) is that it can locate the items that achieve the appropriate model suitability index (Kline 2000).

In addition, Exploratory Factor Analysis (EFA) also serves as an analysis unit that can formulate, classify items and determine new variables that are appropriate and match the objectives to be achieved in the study (Hair et al. 2010). Even according to Mohd Sahrul Syukri et al. (2019) through Exploratory Factor Analysis (EFA), the number of variables will be able to be identified based on the findings from the study sample feedback. This will have a positive effect on the objectives to be achieved specifically.

The stages that need to be passed during the Exploratory Factor Analysis (EFA) are three stages, namely; (1) extract factors, (2) rotate factors, and (3) interpret factors. The purpose of the factor extraction process is to classify items according to components. The process of extracting factors also aims to obtain the same factors (common factors). At the same time, the third process is to interpret the factors that are the process of examining the content of items in each component to identify the theme shared by each item. It is to ensure that each item classified under each variable meets the component interpretation.

\section{OBJECTIVE}

This research attempted to validate the Existing Arabic Language Reading Knowledge Instrument (SPSAMBA) or Students' Prior Knowledge Reading in Arabic Questionnaire (SPKRAQ) among trainee teachers at the Institute of Teacher Education.

\section{METHODOLOGY}

This pilot study involved a total of 150 trainee teachers in the field of Arabic Language and Islamic Education at the Institute of Teacher Education. This amount is suitable for pilot studies involving exploratory factor analysis (EFA) (Hair et al. 2010). The questionnaire instrument called the Existing Arabic Language Reading Knowledge Instrument (SPSAMBA) or Students' Prior Knowledge Reading in Arabic Questionnaire (SPKRAQ) was developed due to the lack of existing instruments. This instrument was based on Schematic Theory in Reading and The Model of Prior Knowledge Hailikari, Nevgi \& LindblomYlanne (2007).

The items in the questionnaire employed a 5-point Likert scale (ordinal scale) namely Extremely Disagree (STS), Disagree (TS), Disagree (KS), Agree (S) and Extremely Agree (SS) and in the form of a positive statement. The initial questionnaire containing 28 items was analysed using Statistical Package for the Social Sciences (SPSS) version 25.

\section{DISCUSSION}

\section{Exploratory Factor Analysis of Existing Knowledge Construct}

The three stages of Exploratory Factor Analysis (EFA), namely extract factors, rotate factors and interpret factors were carried out carefully to achieve the objectives of the study. Before the factor extraction stage was carried out, Bartlett's Test of Sphericity (BToS) and Kaiser-Meyer-Olkin (KMO Kaiser-Meyer-Olkin Measure of Sampling Adequacy) values were identified to achieve the values required to enable data analysis using EFA.

Kaiser-Meyer-Olkin (KMO) aims to test whether a partial correlation between components is small. Bartlett's Test of Sphericity (BtoS) tests whether the matrix correlation is an identity matrix that indicates the factor model is inappropriate. This study employed Streiner and Norman (2008) guidelines which set the KMO value to be above 0.7 (moderate), and the BToS value must be significant $(\mathrm{p}<0.001)$ which allows a set of data to 
be analysed using EFA (Streiner \& Norman 2008).

$\mathrm{KMO}$ and BtoS test results are as follows:

TABLE 1: KMO and Bartlett's test results

\begin{tabular}{lll}
\hline \multicolumn{2}{c}{ KMO and Bartlett's exams } \\
\hline KMO Test (Kaiser-Meyer-Olkin) & .858 \\
& & 2157.69 \\
BToS test & Chi-Square square estimate & 9 \\
(Bartlett's Test of & $\mathrm{df}$ & 351 \\
Sphericity) & Significance & .000 \\
\hline
\end{tabular}

The KMO value obtained was 0.858 , which is at a good level (Streiner \& Norman 2008). These results indicated that partial correlation was small. The value of BToS $(2157,699)$ also demonstrated a significant value, which proved that there was a good correlation in the items of existing knowledge components. Therefore, Exploratory Factor Analysis (EFA) could be carried out.

The first process, which was the extract factor, was carried out in this study using the Maximum Likelihood (ML) of the factor extraction procedure. The purpose of the ML procedure used was to obtain common factors. The same factor seeks to produce the closest sample correlation in the factor (Kline 2000). Additionally, the Maximum Likelihood (ML) procedure is also capable of providing consistent and generalisable results. It is because it does not increase the estimated value of variance (account of variances) (Costello \& Osborne 2005).

Next, this study chose to use the Eigenvalue rules and scree graph to determine the number of components that should be included in the study model. Initial Eigenvalues in excess of 1.00 of the total variance results (Total Variance Explained) would be considered.

The second process was the rotate factor. This process aims to determine the best items that will represent each factor or component (Hair et al. 2010). This study used the Promax type factor rotation procedure. This type of procedure began with a Varimax rotation solution and then increased the coefficient pattern to the highest kappa power (" $\kappa$ "). It tended to force a near-zero coefficient to approach zero faster than a coefficient farther from zero. The procedure continued by generating the smallest squares estimate of the new target matrix by allowing the factors to change together. The next process was to examine the contents of the items of each component so that it could be classified under the appropriate components.

The following is a table of eigenvalues and an accumulated percentage of existing knowledge.

TABLE 2: Eigenvalues and accumulated percentages for existing knowledge construct

\begin{tabular}{|c|c|c|c|c|c|c|}
\hline \multirow[t]{2}{*}{ Factor } & \multicolumn{3}{|c|}{ Initial Eigen Value } & \multicolumn{3}{|c|}{ Total Squared Extraction } \\
\hline & Total & $\begin{array}{c}\text { Variants' } \\
\%\end{array}$ & $\underset{\%}{\text { Accumulated }}$ & Total & $\begin{array}{c}\text { Variants } \\
\%\end{array}$ & $\begin{array}{c}\text { Accumulated } \\
\%\end{array}$ \\
\hline 1 & 8.662 & 32.081 & 32.081 & 8.662 & 32.081 & 32.081 \\
\hline 2 & 4.045 & 14.980 & 47.062 & 4.045 & 14.980 & 47.062 \\
\hline 3 & 1.748 & 6.475 & 53.537 & 1.748 & 6.475 & 53.537 \\
\hline 4 & 1.268 & 4.695 & 58.232 & 1.268 & 4.695 & 58.232 \\
\hline 5 & 1.009 & 3.738 & 61.970 & 1.009 & 3.738 & 61.970 \\
\hline 6 & .952 & 3.527 & 65.497 & & & \\
\hline 7 & .912 & 3.376 & 68.873 & & & \\
\hline 8 & .804 & 2.979 & 71.852 & & & \\
\hline
\end{tabular}




\begin{tabular}{cccc}
\hline 9 & .722 & 2.672 & 74.524 \\
10 & .680 & 2.520 & 77.044 \\
11 & .624 & 2.313 & 79.357 \\
12 & .580 & 2.147 & 81.504 \\
13 & .564 & 2.090 & 83.594 \\
14 & .492 & 1.822 & 85.416 \\
15 & .472 & 1.749 & 87.165 \\
16 & .447 & 1.654 & 88.820 \\
17 & .425 & 1.575 & 90.395 \\
18 & .398 & 1.474 & 91.869 \\
19 & .368 & 1.364 & 93.233 \\
20 & .353 & 1.308 & 94.541 \\
21 & .292 & 1.082 & 95.623 \\
22 & .268 & .992 & 96.615 \\
23 & .231 & .857 & 97.472 \\
24 & .208 & .770 & 98.242 \\
25 & .174 & .645 & 98.887 \\
26 & .160 & .593 & 99.481 \\
27 & .140 & .519 & 100.000
\end{tabular}

Extraction Method: Maximum Likelihood

The table from the results of Exploratory Factor Analysis (EFA) analysis of the existing knowledge component items showed that there were five factors with Eigen exceeded 1.00 were obtained. These values represented $61.970 \%$ for the accumulated percentage of variance. Component 1 contributed $32.081 \%$, component 2 contributed $14.980 \%$, group 3 accounted for $6.475 \%$, group 4 accounted for $4.695 \%$ and group 5 accounted for $3.738 \%$.
The scree graph also exhibited the inclined portion of the vertical graph starting from the first component to the fifth component only. While the graph of the sixth component and so on began to flatten. Therefore, the total subcomponents that would be measured by the 27 items of the trainee teacher's existing knowledge questionnaire were as many as five subcomponents. The scree graph is as follows:

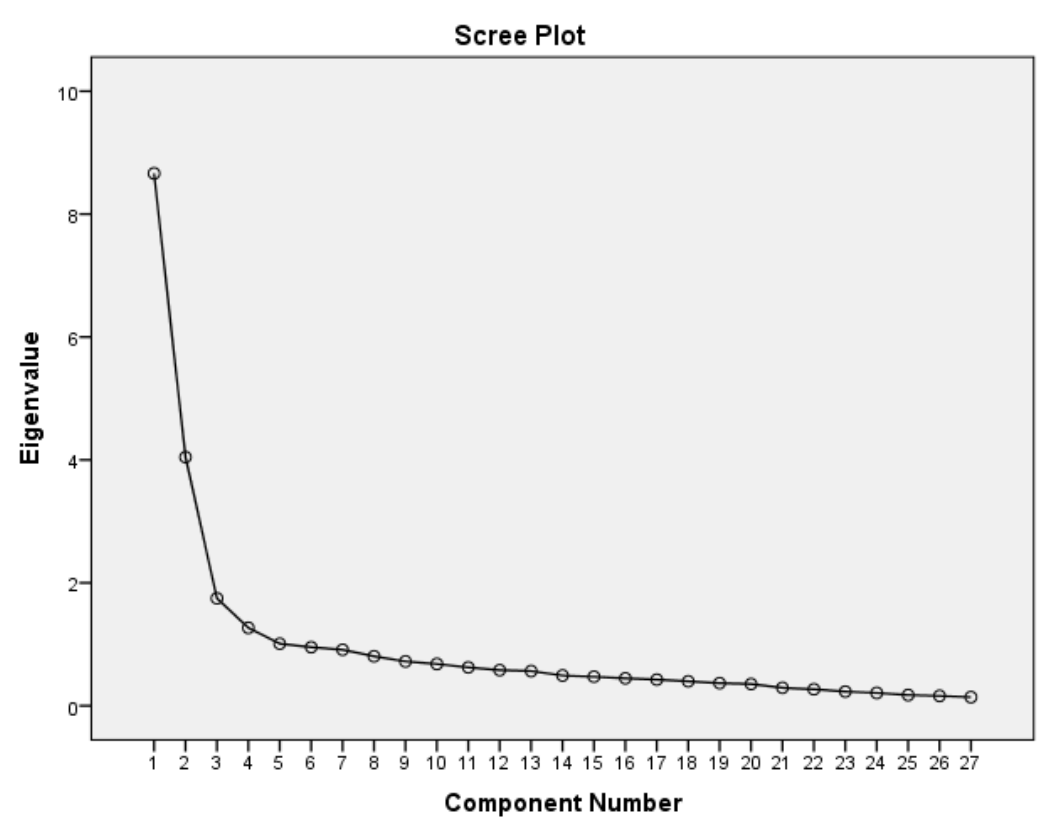


Next, this study adopted the guidance suggested by Hair et al. (2010) and Streiner \& Norman (2008) to select items whose factor load value exceeded 0.5 , which is considered necessary for practical and more significant significance. The following table is the load value of the matrix rotation factor of the existing knowledge component.

TABLE 3: The load value of the matrix rotation factor of existing knowledge components

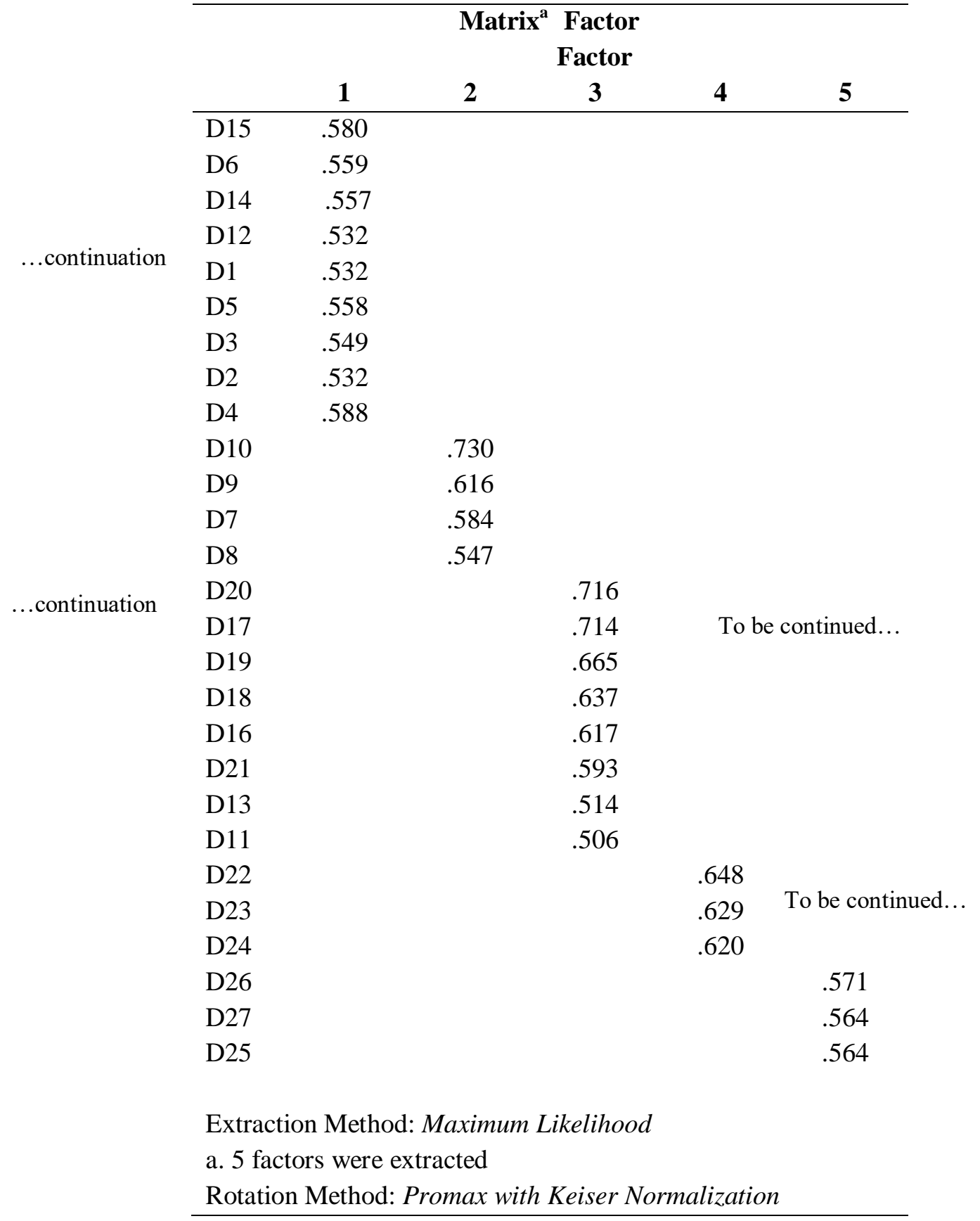

The Exploratory Factor Analysis (EFA) test was continued by examining the content in the items of each sub-component to identify the themes shared by each item. The findings of the analysis showed that the first sub-component relates to grammar knowledge, the second refers to information on topics and content in reference books, the third relates to in-depth information on Arabic language and the contents of reference books, the fourth relates to the integration of knowledge and the fifth relates to practising Arabic information and content.

The third stage in Exploratory Factor Analysis (EFA) practised in this study was to 
interpret the factors. Once five sub-components were identified, this study continued by interpreting each of these subcomponents. Table 4 explains the new themes to interpret the factors.

TABLE 4: Interpretation of existing knowledge factor subcomponents

\begin{tabular}{ll}
\hline \multicolumn{1}{c}{ Sub-component } & \multicolumn{1}{c}{ Interpretation } \\
\hline Sub1 : grammar knowledge & Knowledge of Arabic Grammar \\
Sub2 : information on titles and content in & Book Content Knowledge \\
reference books & \\
Sub3 : in-depth information on Arabic and & In-Depth Knowledge \\
the contents of reference books & \\
Sub4 : knowledge integration & Knowledge Integration \\
Sub5 : knowledge implementation & Knowledge Implementation \\
\hline
\end{tabular}

Table 5 explains in detail the items in the new sub-components.

TABLE 5: Classification of new existing knowledge's sub-component items

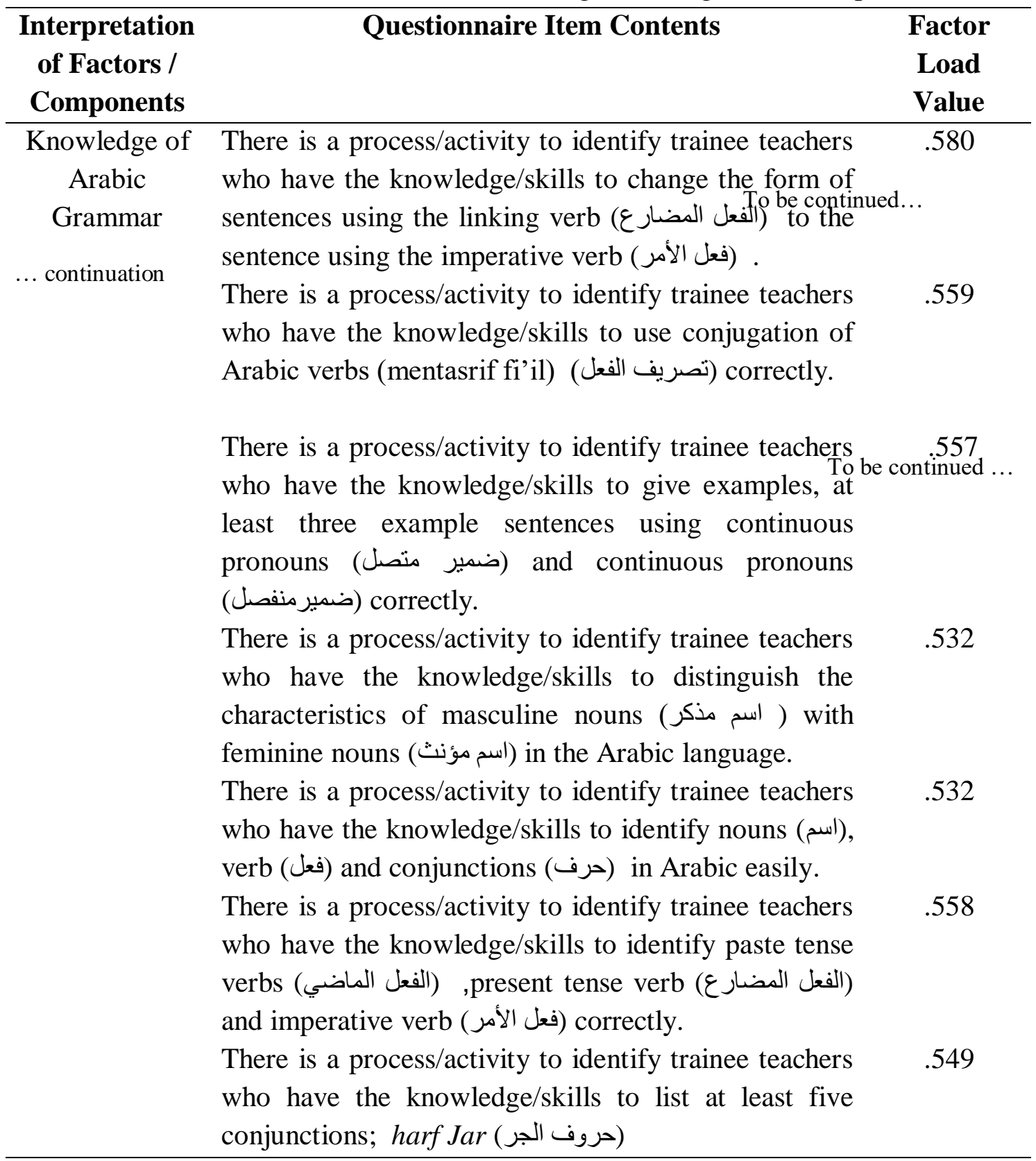


There is a process/activity to identify trainee teachers

who have the knowledge/skills to distinguish between masculine nouns (اسم مذكر) with feminine nouns ( اسم ) (مؤنث).

There is a process/activity to identify trainee teachers who have the knowledge/skills to identify continuous pronouns (ضمير منصل) with discontinuous pronouns correctly.

Content There is a process/activity to identify trainee teachers Knowledge who have the knowledge/writing skills of at least three teaching techniques found in the course reference book Taräiq Tadrīs al-Lughah al- ${ }^{c}$ Arabiah 1 and 2 ( طر ائق تدريس اللغة العربية).

There is a process/activity to identify trainee teachers who have the knowledge/skills to express orally at least ...continuation three teaching strategies found in the course reference book Taräiq Tadrīs al-Lughah al-- Arabiah 1 and 2 ( طر ائق تدريس اللغة العربية).

There is a process/activity to identify trainee teachers who have the knowledge/skills to list at least three main topics in the course Tarāiq Tadrīs al-Lughah al${ }^{c}$ Arabiah 1 and 2 .

( طر ائق تدريس اللغة العربية)

There is a process/activity to identify trainee teachers who have the knowledge/skills to identify at least three teaching methods found in the course reference book Tarāiq Tadrīs al-Lughah al- ${ }^{c}$ Arabiah 1 and 2 ( طر ائق تدريس اللغة العربية).

In-Depth There is a process/activity to identify trainee teachers who have in-depth knowledge/skills related to giving examples of at least three Arabic language teaching strategies found in course reference books Tarāiq Tadrīs al-Lughah al- ${ }^{c}$ Arabiah 1 and 2 ( طر ائق تدريس اللغة) (العربية

There is a process/activity to identify trainee teachers who have in-depth knowledge/skills related to summarising at least three topics learned in the course reference book Tarāiq Tadrīs al-Lughah al- ${ }^{c}$ Arabiah 1 and 2.(طر ائق تدريس اللغة العربية)

There is a process/activity to identify trainee teachers who have in-depth knowledge/skills related to explain at least three teaching methods found in the course reference book Tarāiq Tadrīs al-Lughah al- ${ }^{c}$ Arabiah 1 
and 2

( طر ائق تدريس اللغة العربية)

There is a process/activity to identify trainee teachers who have in-depth knowledge/skills related to explain in-depth the four Arabic language skills learned in the course reference book Tarāiq Tadrīs al-Lughah al${ }^{c}$ Arabiah 1 and 2 ( طر ائق تدريس اللغة العربية).

There is a process/activity to identify trainee teachers who have in-depth knowledge/skills related to correcting the misuse of pronouns (الضمائر) in verse. There is a process/activity to identify trainee teachers who have in-depth knowledge/skills related to criticising at least three Arabic language teaching techniques suggested in the course reference book

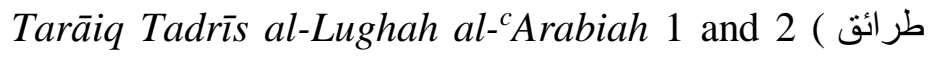
( تدريس اللغة العربية

There is a process/activity to identify trainee teachers who have in-depth knowledge/skills related to recognising mistakes in the use of conjunctions huruf Jar (حروف الجر) in verse.

There is a process/activity to identify trainee teachers who have in-depth knowledge/skills related to explaining the characteristics of nouns (اسم)), verb (فحر) and conjunctions (حرف) Arabic correctly.

To be continued...

Knowledge There are processes/activities of integrating the .648 Integration knowledge of trainee teachers related to modifying the teaching techniques learned in the course Tarāiq Tadrīs al-Lughah al-'Arabiah 1 and 2 (طر ائق تدريس اللغة العربية) for use in other subjects

There are processes/activities of integrating the knowledge of trainee teachers related to the use of teaching methods learned in the course Tarāiq Tadrīs al-Lughah al-'Arabiah 1 and 2(طرائق تدريس اللغة العربية) while teaching Islamic education subjects.

There is a process/activity of integrating the knowledge of trainee teachers related to the concept of Arabic grammar learned helps better to understand the learning of other languages such as English.

Knowledge There is a process/activity of applying the knowledge emails using Arabic. 
There is a process/activity of applying the knowledge

.564

of trainee teachers related to the ability to explain the contents of Arabic reference books read to my friend.

There is a process/activity of applying the knowledge of trainee teachers related to the ability to correct mistakes in Arabic sentences.

Table 6 summarises in detail each aspect of Existing Knowledge related to Factors, Items, Components, Communalities, eigenvalues and percentage variance.

TABLE 6: A detailed summary of each aspect of existing knowledge

\begin{tabular}{|c|c|c|c|c|c|}
\hline Factor & Item & Component & Communality & Eigenvalue & Variance $\%$ \\
\hline Grammar & D15 & .580 & .705 & 8.662 & $32.08 \%$ \\
\hline \multicolumn{6}{|l|}{ Knowledge } \\
\hline & D6 & .559 & .523 & & \\
\hline & D14 & .557 & 554 & & \\
\hline & D12 & .532 & .654 & & \\
\hline & D1 & .532 & .671 & & \\
\hline & D5 & .558 & .596 & & \\
\hline & D3 & .549 & .634 & & \\
\hline & D2 & .532 & .754 & & \\
\hline & D4 & .588 & .629 & & \\
\hline Content & D10 & .730 & .656 & 4.045 & $14.98 \%$ \\
\hline \multicolumn{6}{|l|}{ Knowledge } \\
\hline & D9 & .616 & .581 & & \\
\hline & D7 & .584 & .607 & & \\
\hline & D8 & .547 & .667 & & \\
\hline In-Depth & D20 & .716 & .620 & 1.748 & $6.48 \%$ \\
\hline \multicolumn{6}{|l|}{ Knowledge } \\
\hline & D17 & .714 & .722 & & \\
\hline & D19 & .665 & .606 & & \\
\hline & D18 & .637 & .560 & & \\
\hline & D16 & .617 & .529 & & \\
\hline & D21 & .593 & .502 & & \\
\hline & D13 & .514 & .681 & & \\
\hline & D11 & .506 & .611 & \multicolumn{2}{|c|}{ To be continued.. } \\
\hline \multirow{3}{*}{$\begin{array}{l}\text { Knowledge } \\
\text { tition.... } \\
\text { Integration }\end{array}$} & D22 & .648 & .596 & 1.268 & $4.70 \%$ \\
\hline & D23 & .629 & .529 & & \\
\hline & D24 & .620 & .521 & & \\
\hline \multirow{4}{*}{$\begin{array}{l}\text { Knowledge } \\
\text { Application }\end{array}$} & D26 & .571 & .800 & 1.009 & $3.74 \%$ \\
\hline & & & & & \\
\hline & D27 & .564 & .685 & & \\
\hline & D25 & .564 & .641 & & \\
\hline
\end{tabular}


Based on table 6, the sub-groups of Grammar Knowledge (eigenvalue $=8.662$; percentage of variance $=32.08 \%$ ), Content Knowledge (eigenvalue $=4.045$; percentage of variance $=14.98 \%), \quad$ In-Depth Knowledge (eigenvalue $=1.748$; percentage of variance $=$ $6.48 \%$ ) , Knowledge Integration (eigenvalue $=$ 1.268; percentage of variance $=4.70 \%$ ) and Knowledge Applications (eigenvalue $=1.009$; percentage of variance $=3.74 \%$ ).

\section{Reliability of Existing Knowledge Instrument}

The Existing Arabic Language Reading Knowledge Instrument (SPSAMBA) used the views of Borg and Gall (1979) who set the value of $\alpha=.90$ to .95 as sufficient (sufficient coefficient) in determining the value of the reliability coefficient of the instrument. Table 7 is the value of the SPSAMBA reliability coefficient.

TABLE 7: The value of the SPSAMBA reliability coefficient

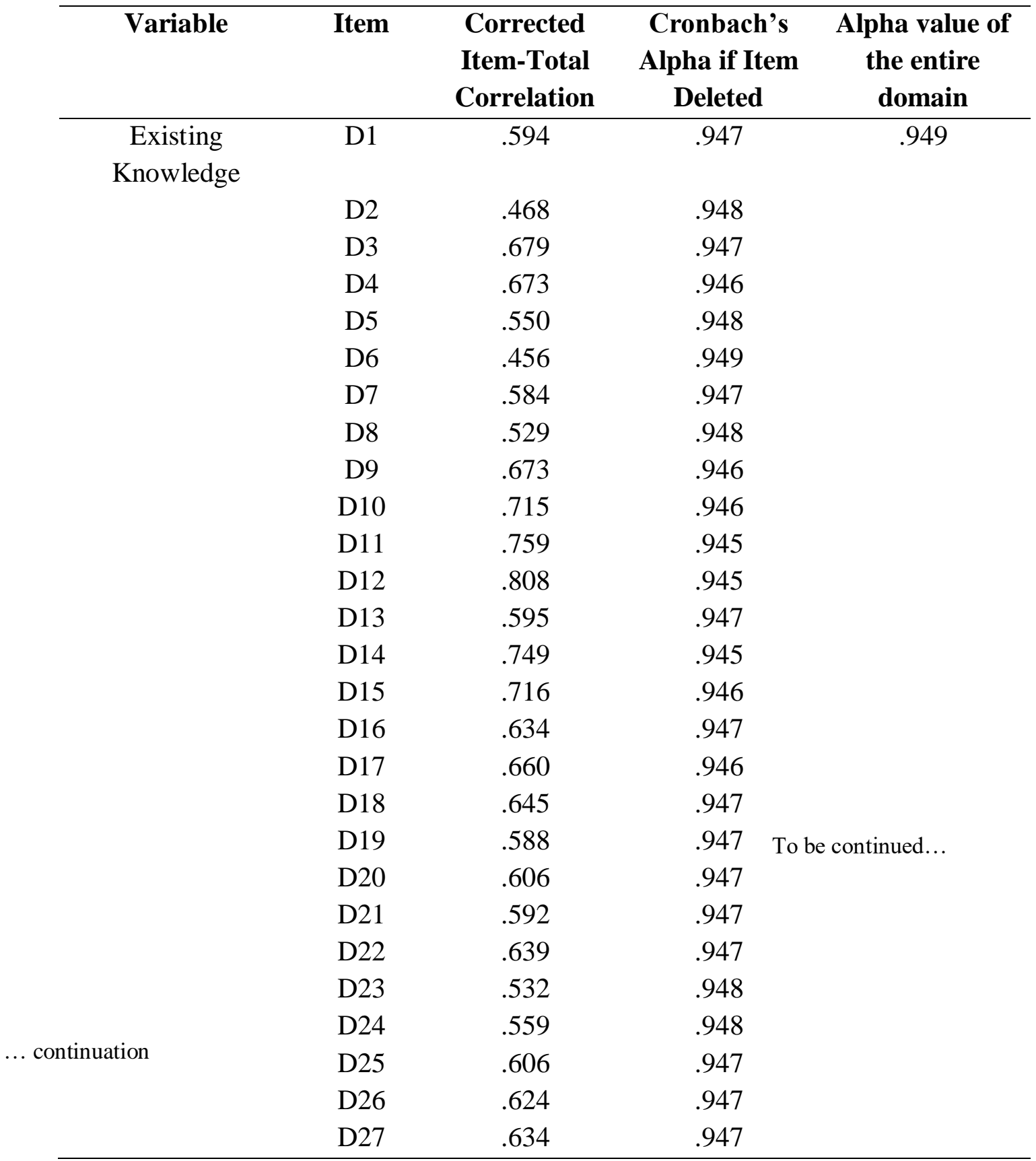


Table 7 shows that each item in the Existing Arabic Language Reading Knowledge Instrument (SPSAMBA) questionnaire had an accepted reliability index value with a Cronbach's Alpha value ranging from 0.946 to 0.949 . At the same time, the overall Cronbach's Alpha value was 0.949 . The correlation value of the corrected item with the total score was greater than 0.3. It means that all items were accepted and remained used as items in the actual study.

\section{CONCLUSION}

The outcomes of this research established that this questionnaire instrument had a level of reliability of the value of the overall Cronbach's Alpha coefficient that could be used in the study, which was 0.949. Exploratory Factor Analysis (EFA) findings presented an Existing Knowledge construct consisting of five sub-constructs particularly Arabic Grammar Knowledge, Content Knowledge, In-depth Knowledge, Knowledge Integration and Knowledge Application with each item having a satisfactory loading factor exceeded 0.5 . Ergo, this questionnaire instrument is reliable and valid to be employed in prospective pieces of knowledge to measure aspects of trainee teachers' existing knowledge on the readability of Arabic language reference books at the Institute of Teacher Education.

\section{REFERENCE}

[1] An, S. 2013. Schema Theory in Reading. Theory and Practice in Language Studies 3(1): 130-134. doi:10.4304/tpls.3.1.130134

[2] Armbruster, B. B. 1986. Schema Theory and the Design of Content-Area Textbooks. Educational Psychologist 21(4): 253-267. doi:10.1207/s15326985ep2104_2

[3] Borg, W. R. \& Gall., M. D. 1979. Educational Research, an Introduction, hlm. 3rd Edisi . New York: Longman.

[4] Carrell, P. L. 1984. Schema Theory and esl Reading: Classroom Implications and Applications. The Modern Language
Journal 68(4): $332-343$ doi:10.1111/j.1540-4781.1984.tb02509.x

[5] Costello, A. \& Osborne, J. 2005. Practical Assessment, Research \& Evaluation. The Journal of Consumer Marketing 10(7): 1-9.

[6] Dahlia Janan. 2011. Towards a New Model of Readability. University of Warwick.

[7] De Corte, E. 1990. Acquiring and teaching cognitive skills. State of the art of theory and research. European perspectives in Pshycology 1.

[8] Dochy, F. 1994. Prior knowledge and learning. International encyclopedia of education. Oxford/New York: Pergamon Press.

[9] Dochy, F., Segers, M. \& Buehl, M. M. 1999. The Relation Between Assessment Practices and Outcomes of Studies: The Case of Research on Prior Knowledge. Review of Educational Research 69(2): 145-186. doi:10.3102/00346543069002145

[10] DuBay, W. H. 2002. Using Readability Tools. In Fourth Biennial Conference Of The PLAIN Language Association International, Toronto 26-29.

[11] Giovanelli, M. \& Mason, J. 2018. Reading, Readers and English. English in Education 52(1): $2-4$. doi:10.1080/04250494.2018.1421343

[12] Gregersen, T. 2006. The despair of disparity: The connection between foreign language anxiety and the recognition of proficiency differences in L2 skills. Lenguas Modernasodernas 31: 7-20.

[13] Hailikari, T. 2009. Assessing University Students' Prior Knowledge, hlm. Vol. Research R. doi:10.1177/0033688206076156

[14] Hailikari, T., Katajavuori, N. \& LindblomYlanne, S. 2008. The relevance of prior knowledge in learning and instructional design. American Journal of Pharmaceutical Education 72(5): 1-8. doi:10.5688/aj7205113 
[15] Hair, J. F., Black, W. C. \& Barry J. Babin. 2010. Multivariate Data Analysis: A Global Perspective, hlm. 7th Edisi . Pearson Education.

[16] Kline, P. 2000. The Handbook of Psychological Testing, hlm. 2nd Editio. Milton Park, Abingdon, Oxon: Routledge: Taylor \& Francis Group.

[17] Lyngfelt, A. 2017. Reading in your first and second language. On the use of prior knowledge when processing fictional texts at school. Social Sciences and Education Research Review 4(2): 78-99.

[18] Mohd Sahrul Syukri, Farahein, N. \& Samat, N. 2019. Penggunaan Analisis Faktor Bagi Menentukan Faktor Pendorong Kemiskinan Isi Rumah Di Wilayah Utara Semenanjung Malaysia. Penggunaan Analisis Faktor Bagi Menentukan Faktor Pendorong Kemiskinan Isi Rumah Di Wilayah Utara Semenanjung Malaysia 16(6): 1-18.

[19] Pankin, J. 2013. Schema Theory Basic Concepts. Web.Mit 1-5. Retrieved from http://web.mit.edu/pankin/www/Schema Theory_and_Concept_Formation.pdf

[20] Rosenblatt, L. M. 1988. Technical report no. 416: Writing and reading: The transactional theory. Center for the Study of Reading 1-18.

[21] Schumacker, R. E. \& Lomax, R. G. 2016. A Beginner's Guide to Structural Equation Modeling, hlm. 4th New ed. London, United Kingdom: Taylor \& Francis Ltd.

[22] Shukery Mohamed \& Zaharah Abdullah. 1999. Kepentingan Pengetahuan Satu Sorotan Ringkas. Jurnal Pendidik dan Pendidikan Jilid 16: 85-94.

[23] Streiner, D. L. \& Norman, G. R. 2008. Health Measurement Scales: A Practical Guide to Their Development and Use, hlm. 4th Editio. New York: Oxford University Press.

[24] Urquhart, A. H. \& Weir, C. J. 1998. Reading in a Second Language: Process,
Product and Practice, hlm. 1st Edisi . New York: Routledge.

[25] Zulazhan, A. H. 2012. Kebolehbacaan Buku Teks Balaghah Sijil Tinggi Agama Malaysia di Sekolah-sekolah Menengah Agama Negeri. Universiti Kebangsaan Malaysia. 